\title{
Spatial variations in methane emissions from natural wetlands in China
}

\author{
X. Zhang $\cdot$ H. Jiang
}

Received: 6 October 2011/Revised: 29 April 2012/Accepted: 5 November 2012/Published online: 3 December 2013

(C) Islamic Azad University (IAU) 2013

\begin{abstract}
Natural wetlands are thought to be one of the largest natural sources of atmospheric methane concentrations. Although numerous studies referred to the rate of methane fluxes in different geophysical regions, only a few had estimates of the overall geographical methane emissions in China. This study estimated the spatial variations of annual methane emissions with the pixel size of $1 \mathrm{~km} \times 1 \mathrm{~km}$ from natural wetlands, excluding water surface, in China. The natural wetland areas were extracted from the database of the 2000 land covers, and geophysical divisions were used to represent different climate conditions. Methane emission in every geophysical region was calculated based on methane release factors obtained from an extensive overview of published literature and the data of elevation and vegetation proportion. The estimated annual methane emissions ranged from 0 to $5,702.8 \mathrm{~kg}$ per pixel within the area of $1 \mathrm{~km}^{2}$, and the spatial variation in methane emissions was strongly correlated with proportion of wetlands in the area. The total methane emission from natural wetland in China ranged from 3.48 to $7.16 \mathrm{Tg}$ (terrogram, unit of weight) per year, with the mean value of $4.94 \mathrm{Tg}$ per year, based on the area $133,000 \mathrm{~km}^{2}$ of natural wetlands. Specifically, the wetland in Northeast China had the highest contribution in China (39\%). Inner Mongolia and Qinghai-Tibet highland represented for about 25 and
\end{abstract}

\section{Zhang $(\bowtie) \cdot$ H. Jiang}

International Institute for Earth System Science,

Nanjing University, Nanjing 210093, China

e-mail: 1zhxy77@163.com

\section{H. Jiang}

State Key Laboratory of Subtropical Forest Science and Zhejiang Provincial Key Laboratory of Carbon Cycling in Forest Ecosystems and Carbon Sequestration, Zhejiang Agriculture and Forestry University, Hangzhou 311300, China
$21 \%$, respectively. The other $15 \%$ of the measured methane was released in Northwest, North, Central, and South China.

Keywords Methane release - Geophysical region · Plant types $\cdot$ Wetland distribution

\section{Introduction}

Next to water vapor and carbon dioxide, methane $\left(\mathrm{CH}_{4}\right)$ is considered as the most abundant greenhouse gas in the troposphere, affecting both the natural environment and human health (Bicheldey and Latushkina 2010; Zhang et al. 2011, 2012). Natural wetlands are thought to be one of the largest natural sources, contributing $20 \%$ of the global annual flux of $\mathrm{CH}_{4}$ to the atmosphere (Bachelet and Neue 1993). $\mathrm{CH}_{4}$ production and emission in wetlands involve complex physiological processes of plants and microorganism, which are regulated by climatic and environmental factors (Ding et al. 2004; Chang and Yang 2003). Therefore, considerable uncertainties exist in estimates of $\mathrm{CH}_{4}$ emissions levels and fluxes from natural wetland at regional scale.

In recent years, $\mathrm{CH}_{4}$ emissions from natural wetlands around China have been given a lot of attention, most of which were conducted in boreal zones and different temperature zones in China. Most of theses studies used closed chamber to monitor gas exchanges between the biosphere and atmosphere. The detailed information is listed in Table 1. In Qianghai-Tibetan Plateau, Jin et al. (1999) observed strong spatial and temporal variations in Huashixia. Hirota et al. (2004) mentioned in his study that $\mathrm{CH}_{4}$ fluxes from different vegetation zones in Luanhaizi wetland increased with increasing aboveground biomass and 
Table 1 Methane fluxes from natural wetland in China

\begin{tabular}{|c|c|c|c|c|}
\hline Wetland & Measured period & Investigators & Vegetation/wetland type & $\begin{array}{l}\text { Mean } \mathrm{CH}_{4} \text { fluxes } \\
\left(\mathrm{mg} \mathrm{CH}_{4} \mathrm{~m}^{-2} \mathrm{~h}^{-1}\right)\end{array}$ \\
\hline \multirow[t]{7}{*}{ Xiao-xing' anling } & $2007 / 5-10$ & Sun et al. (2011) & Carex schmidtii and Calamagrostis angustifolia & 19.03 \\
\hline & $2008 / 5-10$ & & Betula ovalifolia & 0.27 \\
\hline & & & Alnus sibirica & 9.97 \\
\hline & & & Betula platyphylla & 0.45 \\
\hline & & & Larix gmelinii-Carex schmidtii & -0.03 \\
\hline & & & Larix gmelinii-Moss & -0.06 \\
\hline & & & Larix gmelinii-Sphagnum spp. & 1.09 \\
\hline \multirow[t]{12}{*}{ Sanjiang Plain } & $2001 / 5-10$ & Ding et al. (2004) & Carex lasiocarpa & 19.6 \\
\hline & $2002 / 5-10$ & & & \\
\hline & $2001 / 8$ & Ding et al. (2005) & Carex meyeriama & 23.8 \\
\hline & $2002 / 8$ & & Deyeuxia angustifolia & 21.85 \\
\hline & $2002 / 5-10$ & Song et al. (2008) & Carex lasiocarpa & 11.15 \\
\hline & $2003 / 5-10$ & & Deyeuxia angustifolia & 6.24 \\
\hline & $2004 / 5-10$ & & Shrub & 0.24 \\
\hline & $2003 / 6-9$ & Song et al. (2006) & Carex lasiocarpa & 11.40 \\
\hline & & & Deyeuxia angustifolia & 1.59 \\
\hline & & & C. pseudocuraica & 10.80 \\
\hline & $11-12$ & Zhang et al. (2005) & Carex lasiocarpa & 0.5 \\
\hline & $1-4$ & & Deyeuxia angustifolia & 0.18 \\
\hline Liaohe Delta & $4-11$ & Huang et al. (2011) & Phragmites australis & 0.52 \\
\hline \multirow[t]{8}{*}{ Zoige Plateau } & $2001 / 5-9$ & Ding et al. (2004) & Carex muliensis & 2.06 \\
\hline & $2002 / 5-9$ & & Carex meyeriana & 3.88 \\
\hline & $2005 / 6-9$ & Chen et al. (2008) & Carex muliensis & 22.85 \\
\hline & & & Eleocharis valleculosa & 14.1 \\
\hline & & & Dry hummock & 6.79 \\
\hline & 2006/12-2007/1-2 & Zhu et al. (2011) & Carex muliensis & 2.74 \\
\hline & 2007/12-2008/1-2 & & Eleocharis valleculosa & 0.87 \\
\hline & & & Dry hummock & 0.08 \\
\hline \multirow[t]{6}{*}{ Huahu } & $2006 / 6-8$ & Chen et al. (2009b) & G. maxima & 45.0 \\
\hline & $2007 / 6-8$ & & K. tibetica & 0.60 \\
\hline & & & H. vulgaris & 11.1 \\
\hline & & & C. muliensis & 4.60 \\
\hline & & & Bare shore & 4.90 \\
\hline & & & P. amphibium & 4.90 \\
\hline Huashi-xia & $1997 / 5-9$ & Jin et al. (1999) & - & 1.69 \\
\hline \multirow[t]{4}{*}{ Luanhaizi } & $2002 / 7-9$ & Hirota et al. (2004) & Carex allivesers & 9.00 \\
\hline & & & Scirpus distigmaticus & 5.80 \\
\hline & & & Hippuris vulgaris & 12.1 \\
\hline & & & Potamogeton pectinatus & 2.40 \\
\hline \multirow[t]{5}{*}{ Taihu } & 2003/8-2004/8 & Wang et al. (2006a) & Infralittoral zone & 10.0 \\
\hline & & & Eulittoral zone & 2.60 \\
\hline & & & Bare shore & 0.4 \\
\hline & & & Pelagic zone & 0.50 \\
\hline & & & Supralittoral zone & 0.10 \\
\hline \multirow[t]{2}{*}{ Yangtze Estuary } & 2004/8-2005/7 & Wang et al. $(2009 a, b)$ & Middle flat & 2.06 \\
\hline & & & Low flat & 0.04 \\
\hline
\end{tabular}


Table 1 continued

\begin{tabular}{|c|c|c|c|c|}
\hline Wetland & Measured period & Investigators & Vegetation/wetland type & $\begin{array}{l}\text { Mean } \mathrm{CH}_{4} \text { fluxes } \\
\left(\mathrm{mg} \mathrm{CH}_{4} \mathrm{~m}^{-2} \mathrm{~h}^{-1}\right)\end{array}$ \\
\hline \multirow[t]{6}{*}{ Min River Estuary } & \multirow[t]{6}{*}{$2007 / 1-12$} & \multirow[t]{6}{*}{ Tong et al. (2010) } & Phragmites australis & 4.34 \\
\hline & & & Cyoerus malaccensis & 4.65 \\
\hline & & & Scirpus triqueter & 0.71 \\
\hline & & & Bare shore & 5.54 \\
\hline & & & Spartina alterniflora & 11.02 \\
\hline & & & Phragmites australis & 4.98 \\
\hline \multirow[t]{2}{*}{ Tai-wan } & \multirow[t]{2}{*}{ 1995/9-1999/4 } & \multirow[t]{2}{*}{ Chang and Yang (2003) } & - & 1.82 \\
\hline & & & - & 0.14 \\
\hline Hai-nan & $1997 / 5,11$ & Lu et al. (1999) & Mangrove & 0.03 \\
\hline Wu-liangsu & $2003 / 4-10$ & Duan et al. (2005) & Phragmites communis & 8.75 \\
\hline \multirow[t]{2}{*}{ Xilin River basin } & $2003-2005 / 4-10$ & \multirow[t]{2}{*}{ Wang et al. (2009b) } & \multirow[t]{2}{*}{-} & 13.18 \\
\hline & $11-12,1-3$ & & & 3.1 \\
\hline
\end{tabular}

the spatial and temporal variation in $\mathrm{CH}_{4}$ flux that was determined by vegetation zones. Ding and his collaborators (Ding et al. 2004; Ding and Cai 2007) measured the seasonal variations in $\mathrm{CH}_{4}$ fluxes from carex wetland, and they concluded that water and temperature were the key factors to influence the emission rate of $\mathrm{CH}_{4}$. Chen and his collaborators (Chen et al. 2008, 2009a, b; Zhu et al. 2011) discussed the spatial and temporal variations in $\mathrm{CH}_{4}$ emissions that resulted from these variations in temperature, plant growth, and water factors.

In Northeast China, researchers at the Northeast Institute of Geography, Agricultural and Ecology (Zhang et al. 2005; Song et al. 2006, 2008; Sun et al. 2011), in collaboration with the State Key Laboratory of Soil and Sustainable Agriculture (Ding et al. 2004, 2005; Ding and Cai 2007), measured $\mathrm{CH}_{4}$ fluxes from herbaceous swamp and forested wetland, and discussed the spatial and temporal variations in $\mathrm{CH}_{4}$ fluxes and their influencing factors. They found that standing water depth determined the type of marsh plants, which governed $\mathrm{CH}_{4}$ transport and the amount the of plant litters (Sun et al. 2011; Ding and Cai 2007).

In North China, there was only one report on $\mathrm{CH}_{4}$ emission from Phragmites australis in Liaohe Delta (Huang et al. 2011). Field experiments showed that this wetland acted as a $\mathrm{CH}_{4}$ sink in spring, a strong source in summer, and a weak source in autumn, and this temporal variation was positively related to temperature and negatively related to Eh (soil redox potential) value and water depth. In inner Mongolia, two measurements were carried out in the middle and lower reaches of large rivers and lakes in semiarid region (Duan et al. 2005; Wang et al. 2005, 2009b) and showed that vegetation cover, water depth, bottom silt temperature, and light intensity were important factors influencing seasonal and diurnal variation in $\mathrm{CH}_{4}$ flux.
In the two geophysical regions of South and Central China, $\mathrm{CH}_{4}$ fluxes from natural wetlands were measured over one year. Yangtze and Min River Estuary, Taihu, Taiwan, and Hainan attracted much attention (Lu et al. 1999; Chang and Yang 2003; Wang et al. 2009a; Tong et al. 2010). These studies showed that $\mathrm{CH}_{4}$ emissions from herbaceous swamps were much higher than those from mangroves, and the emission rates from beaches were greatly influenced by tidal stages.

Although numerous studies referred to the rate of $\mathrm{CH}_{4}$ fluxes in different types of geophysical regions, only a few made estimates about overall geographical $\mathrm{CH}_{4}$ emissions from natural wetlands in China. Ding et al. (2004), and Ding and Cai (2007) discussed the spatial and temporal variations in $\mathrm{CH}_{4}$ releases from natural wetlands in Northeast China and Qianghai-Tibetan Plateau, estimated total emissions based on their in situ measurements, and showed the available $\mathrm{CH}_{4}$ fluxes measured in North China, South China, and Qianghai-Tibetan Plateau (Huang et al. 2011; Lu et al. 1999; Jin et al. 1999). The preliminarily estimated emissions levels of $\mathrm{CH}_{4}$ from natural wetlands in China were $1.48 \mathrm{Tg}$ (terrogram, unit of weight) $\mathrm{CH}_{4}$ over growing season and $1.76 \mathrm{Tg} \mathrm{CH}_{4}$ per year (Ding et al. 2004). However, the huge spatial and seasonal variations in $\mathrm{CH}_{4}$ emission from natural wetlands are observed in the mentioned monitoring stations, and regional differences can be significant, even when the sites are similar in climate, vegetation, and topography (Yavitt et al. 1988; Ding et al. 2004). Improving the assessment of $\mathrm{CH}_{4}$ emissions from natural wetlands of China, requires having additional field measurements of $\mathrm{CH}_{4}$ fluxes in various kinds of vegetation and climate conditions as well as additional information about the various wetland areas.

This study estimates the spatial distribution of $\mathrm{CH}_{4}$ release from natural wetlands (excluding water surface) 
around China based on existing investigations on $\mathrm{CH}_{4}$ fluxes from the 1990s and 2000s. The investigations were conducted in 2007 and 2008 at Xiaoxing' anling $\left(128^{\circ} 38^{\prime} \mathrm{E}\right.$, $48^{\circ} 7^{\prime} \mathrm{N}$ ), from 1995 to 1996 , and from 2001 to 2004 at Sanjing Plain $\left(133^{\circ} 13^{\prime} \mathrm{E}, 47^{\circ} 35^{\prime} \mathrm{N}\right)$, in 2000 at Liaohe Delta $\left(121^{\circ} 35^{\prime} \mathrm{E}, 40^{\circ} 52^{\prime} \mathrm{N}\right)$, in 2001 and 2002 at Ruoergan Plateau $\left(102^{\circ} 32^{\prime} \mathrm{E}, 32^{\circ} 47^{\prime} \mathrm{N}\right)$, from 2005 to 2007 at Wetland National Nature Reserve of Zoige $\left(102^{\circ} 52^{\prime} \mathrm{E}, 33^{\circ} 56^{\prime} \mathrm{N}\right)$, in 2006 and 2007 at Huahu $\left(102^{\circ} 2^{\prime} \mathrm{E}, 33^{\circ} 6^{\prime} \mathrm{N}\right)$, in 1997 at Huashixia $\left(98^{\circ} 48^{\prime} \mathrm{E}, 35^{\circ} 39^{\prime} \mathrm{N}\right)$, in 2002 at Luanhaizi $\left(102^{\circ} 12^{\prime} \mathrm{E}, 37^{\circ} 29^{\prime} \mathrm{N}\right)$, in 2003 and 2004 at Taihu $\left(120^{\circ} \mathrm{E}\right.$, $\left.31^{\circ} \mathrm{N}\right)$, in 2004 and 2005 at Yangtze Estuary $\left(121^{\circ} 30^{\prime} \mathrm{E}\right.$, $\left.31^{\circ} 39^{\prime} \mathrm{N}\right)$, in 2007 at Min River Estuary $\left(119^{\circ} 34^{\prime}-\right.$ $\left.119^{\circ} 40^{\prime} \mathrm{E}, 26^{\circ} 32^{\prime}-26^{\circ} 36^{\prime} \mathrm{N}\right)$, from 1995 to 1999 at Kuandu $\left(120^{\circ} 27^{\prime} \mathrm{E}, 25^{\circ} 7^{\prime} \mathrm{N}\right)$ and Kangnan $\left(120^{\circ} 53^{\prime} \mathrm{E}\right.$, $\left.24^{\circ} 45^{\prime} \mathrm{N}\right)$ of Taiwan, in 1997 at Hainan $\left(110^{\circ} 24^{\prime} \mathrm{E}\right.$, $\left.19^{\circ} 51^{\prime} \mathrm{N}\right)$, in 2003 at Wuliangsu $\left(108^{\circ} 43^{\prime}-108^{\circ} 57^{\prime} \mathrm{E}\right.$, $\left.40^{\circ} 47^{\prime}-41^{\circ} 3^{\prime} \mathrm{N}\right)$, and from 2003 to 2005 at Xilin River basin $\left(115^{\circ} 32^{\prime}-117^{\circ} 12^{\prime} \mathrm{E}, 43^{\circ} 26^{\prime}-44^{\circ} 39^{\prime} \mathrm{N}\right)$. This analysis was made to supply the national greenhouse gas inventories, giving updated background information about $\mathrm{CH}_{4}$ released from natural sources in China, and it also could improve the estimates of the global carbon levels, and provide helpful information that could enhance carbon sequestration capacity in China.

\section{Materials and methods}

\section{Databases}

As any area is considered as fully natural state, for this study, "natural" covers all wetlands as determined 2000 National Land Survey Data from the Data Sharing Network of Earth System Science (http://www.geodata.cn). The land cover map is derived from remotely sensed data with a spatial resolution of $1 \mathrm{~km} \times 1 \mathrm{~km}$. The values for the land cover map range from 0 to $100 \%$, representing the percentage of this kind of land cover in every $1 \mathrm{~km} \times 1 \mathrm{~km}$ plot. Three types of wetland-related land cover data are extracted: tidal beaches, bottomland, and marshes, with areas of $6,424,82,068$, and $44,417 \mathrm{~km}^{2}$, respectively.

China is divided into 7 physicogeographical regions, considering the conditions of vegetation, climate, soil, and landform. These geophysical regions are named as the Northeast, North, Central, South, and Northwest China, Inner Mongolia, and Qinghai-Tibet Plateau (Fig. 1). In addition, The Shuttle Radar Topographic Mission digital elevation model (DEM) data set (http://eros.usgs.gov/ \#Find_Data/Products_and_Data_Available/gtopo30_info) is used to generate topographic data in China, and helped to identify wetland types.
Method

To obtain the spatial distribution of $\mathrm{CH}_{4}$ emission in China, the pix-based wetland information (http://www.geodata.cn) is used. Methane emission (ME) at each pixel is calculated based on the following equation:

$\mathrm{ME}_{(i, j, m)}=\mathrm{MEG}_{(i, j, m)}+\operatorname{MENG}_{(i, j, m)}$

where $\mathrm{ME}_{(i, j, m)}$ is $\mathrm{CH}_{4}$ flux at the pixel location $(i . j)$ in the geophysical region $m$. $\mathrm{MEG}_{(i, j, m)}$ and $\mathrm{MENG}_{(i, j, m)}$ is $\mathrm{CH}_{4}$ flux during growing season and non-growing season, respectively.

Then, $\mathrm{CH}_{4}$ emission during growing season could be estimated by the equation as follows:

$\operatorname{MEG}_{(i, j, m)}=\mathrm{FG}_{m} A_{(i, j, m)} D_{m}$

where $A_{(i, j, m)}$ is the area of pixel at the location $(i, j)$, which is provided by the land use map. $\mathrm{FG}_{m}$ and $D_{m}$ is the mean $\mathrm{CH}_{4}$ flux (mg $\mathrm{CH}_{4} \mathrm{~m}^{-2} \mathrm{~h}^{-1}$ ) and the duration (h) of plant growth period in $m$ geophysical region, respectively.

$\mathrm{CH}_{4}$ flux shows strong variations from different vegetation types in different geophysical regions. Therefore, the averaged $\mathrm{CH}_{4}$ flux during measured period was calculated by the following equation:

$\mathrm{FG}_{m}=\sum_{n=1}^{N} \mathrm{AP}_{n} F_{m n}$

where $\mathrm{AP}_{n}$ is the area proportion of plant $n$ in the geophysical region $m$, and $F_{m n}$ is the measured $\mathrm{CH}_{4}$ flux from plant $n$ in geophysical region $m$.

If there is no references on vegetation proportion in a geophysical region, mean $\mathrm{CH}_{4}$ values in each study are adopted. And then, these values are averaged again by different studies within the geophysical region as mean $\mathrm{CH}_{4}$ flux.

\section{Results and discussion}

Spatial distribution of natural wetlands in China

The study area was all of China $-9,600,000 \mathrm{~km}^{2}$. About $1.4 \%$ of that area consists of wetlands, which spreads throughout the whole country. As for topographical conditions, natural wetland is found not only at the sea level in the eastern part of China but also on the plateau with an elevation of more than $3,000 \mathrm{~m}$ in southwestern part of China. Most of the natural wetlands are located in Northeast, Southeast China, and Inner Mongolia. Specifically, about $30.62 \%$ is located in Northeast China, $28.27 \%$ in Qinghai-Tibet Plateau, and $16.44 \%$ in Inner Mongolia. The North, Central, Northwest, and South China has 


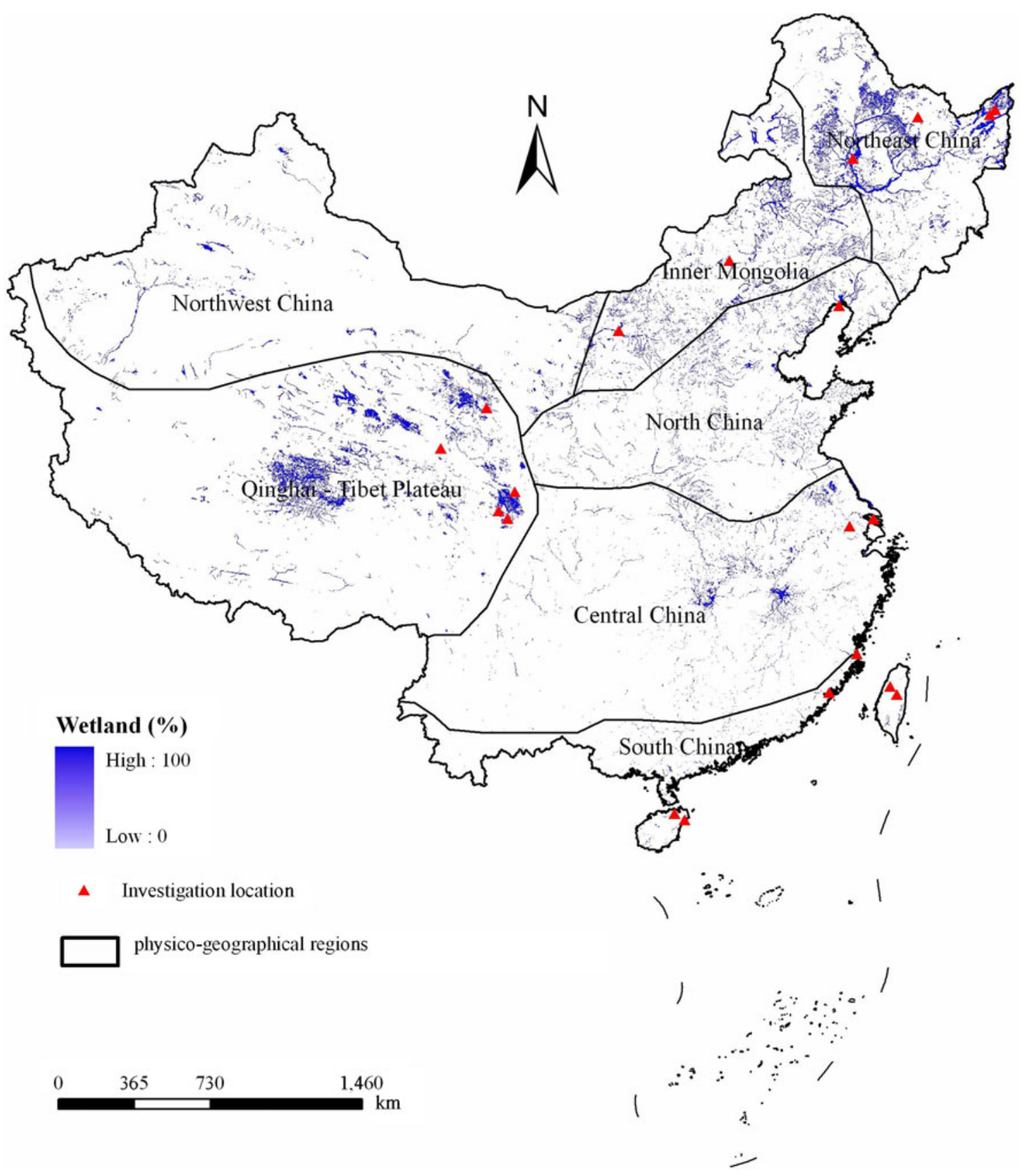

Fig. 1 Spatial distribution of natural wetland and measurements on $\mathrm{CH}_{4}$ fluxes conducted in China

relative low proportion of natural wetland, and the ratio is $8.14,7.8,7.61$, and $1.12 \%$, respectively (Table 2).

In the study of Ding, mentioned that the total area of natural wetland used to estimate $\mathrm{CH}_{4}$ emission is $94,000 \mathrm{~km}^{2}$, of which 51.15 and $30.29 \%$ of natural wetland is located in Qinghai-Tibet highland and Northeast China, respectively (Ding et al. 2004). The big difference in the wetland areas between this study and Ding et al. (2004) might be that the total natural wetland excludes floodplain in Ding et al. (2004), while are included in this study. If the floodplain is not included, the natural wetland in this study is $82,068 \mathrm{~km}^{2}$.

$\mathrm{CH}_{4}$ release factor and duration of plant growth

Wetland plants play an important role in the three main aspects of methane emissions: (a) providing conduits for methane transportation, (b) supplying substrates for methanogens through root exudation, and (c) delivering $\mathrm{O}_{2}$ to oxidize methane through roots to rhizosphere (Schŭtz et al. 
Table 2 Statistics of the natural wetland (excluding water surface) area by geographical regions in China

\begin{tabular}{lrc}
\hline Physico-geographical regions & Area $\left(\mathrm{km}^{2}\right)$ & Proportion $(\%)$ \\
\hline South China & 1,143 & 0.86 \\
South China-Mangrove & 352 & 0.26 \\
Central China & 10,109 & 7.61 \\
Qinghai-Tibet Plateau & 37,577 & 28.27 \\
Northwest China & 10,360 & 7.80 \\
Inner Mongolia & 21,848 & 16.44 \\
North China & 10,818 & 8.14 \\
Northeast China-mountain area & 10,019 & 7.54 \\
Northeast China-plain & 30,684 & 23.09 \\
Total & 132,909 & 100.00 \\
\hline
\end{tabular}

1991). Therefore, strong variations in $\mathrm{CH}_{4}$ release existed among various plant types.

There are five main wetland types in mountain areas in Northeast China. The $\mathrm{CH}_{4}$ release from marsh, thicket swamp, and coniferous forested swamp is calculated from Carex schmidtii and Calamagrostis angustifolia, Betula ovalifolia, Larix gmelinii-C. schmidtii, respectively (Table 1). The emitted $\mathrm{CH}_{4}$ fluxes from the other two wetlands of deciduous forested swamp and forested peatland are estimated according to the averaged $\mathrm{CH}_{4}$ releases from Alnus sibirica and Betula platyphylla, and Larix gmelini-Moss and L. gmelinii-sphagnum spp., respectively. The area proportion of marsh, thicket swamp, coniferous forested swamp, deciduous forested swamp, and forested peatland is $60.43,17.52,19.37,1.01$, and $1.66 \%$. Thus, $F_{m n}$ in mountain area (DEM $>300 \mathrm{~m}$ ) of Northeast China is $11.60 \mathrm{mg} \mathrm{CH}_{4} \mathrm{~m}^{-2} \mathrm{~h}^{-1}$ following Eq. 3 (Table 2). Since there is only one observation reported in this area, the maximum and minimum release factor is the same with the mean value.

Based on the measurements on $\mathrm{CH}_{4}$ emissions in Sanjiang Plain (Table 1), the averaged $\mathrm{CH}_{4}$ flux from Carex hair, C. pseudocuraica, and Deyeuxia angustifolia is $13.16 \mathrm{mg} \mathrm{CH}_{4} \mathrm{~m}^{-2} \mathrm{~h}^{-1}, \quad 4.03 \mathrm{mg} \mathrm{CH}_{4} \mathrm{~m}^{-2} \mathrm{~h}^{-1}$, and $10.80 \mathrm{mg} \mathrm{CH}_{4} \mathrm{~m}^{-2} \mathrm{~h}^{-1}$. The maximum $\mathrm{CH}_{4}$ flux from the above three kinds of plants is $19.65 \mathrm{mg} \mathrm{CH}_{4} \mathrm{~m}^{-2} \mathrm{~h}^{-1}$, $6.48 \mathrm{mg} \mathrm{CH}_{4} \mathrm{~m}^{-2} \mathrm{~h}^{-1}$, and $10.80 \mathrm{mg} \mathrm{CH}_{4} \mathrm{~m}^{-2} \mathrm{~h}^{-1}$, and the minimum value is $10.45 \mathrm{mg} \mathrm{CH}_{4} \mathrm{~m}^{-2} \mathrm{~h}^{-1}, \quad 1.59$ $\mathrm{mg} \mathrm{CH}_{4} \mathrm{~m}^{-2} \mathrm{~h}^{-1}$, and $10.80 \mathrm{mg} \mathrm{CH}_{4} \mathrm{~m}^{-2} \mathrm{~h}^{-1}$. Among herbaceous swamp areas in Sanjiang Plain, C. hair, C. pseudocuraica, and D. angustifolia account for 81.90, 10.50 , and $7.60 \%$, respectively, in Sanjiang Plain. Thus, $\mathrm{CH}_{4}$ emission from herbaceous swamp is $12.03 \mathrm{mg} \mathrm{CH}$ $\mathrm{m}^{-2} \mathrm{~h}^{-1}$, with a maximum value of $17.59 \mathrm{mg} \mathrm{CH}_{4} \mathrm{~m}^{-2} \mathrm{~h}^{-1}$ and a minimum value of $9.55 \mathrm{mg} \mathrm{CH}_{4} \mathrm{~m}^{-2} \mathrm{~h}^{-1}$.

In Qinghai-Tibet Plateau, $\mathrm{CH}_{4}$ flux measurements are taken on many vegetation types. The regional mean $\mathrm{CH}_{4}$ flux is firstly calculated for each study, and then the averaged value from different studies is deemed as the averaged $\mathrm{CH}_{4}$ flux. In Chen study (2008), the coverage of Carex muliensis, Eleocharis valleculosa, and Kobresia tibetica accounts for the study area is 30, 25, and $45 \%$, respectively; thus, the averaged $\mathrm{CH}_{4}$ flux is $13.44 \mathrm{mg} \mathrm{CH}_{4} \mathrm{~m}^{-2} \mathrm{~h}^{-1}$. In Huahu Lake, the area for $G$. maxima, K. tibetica, H. vulgaris, C. muliensis, Bare shore, and $P$. amphibium accounts for $25,15,10,15,20$, and $15 \%$, respectively, and the mean $\mathrm{CH}_{4}$ flux is $15.21 \mathrm{mg} \mathrm{CH}_{4} \mathrm{~m}^{-2} \mathrm{~h}^{-1}$ (Chen et al. 2009b). In Luanhaizi wetland, Carex allivescers V. Krez, Scirpus distigmaticus L., Hippuris vlugaris L., and Potamogeton pectinatus $L$. make up $3.4,20.5,2.6$, and $73.5 \%$ of the study area (Hirota et al. 2004), and the mean $\mathrm{CH}_{4}$ flux is $3.57 \mathrm{mg} \mathrm{CH}_{4} \mathrm{~m}^{-2} \mathrm{~h}^{-1}$. In the study of Ding et al. (2004) and Jin et al. (1999), the mean $\mathrm{CH}_{4}$ flux is calculated by averaging values from the different vegetation types, which is 2.97 and $1.69 \mathrm{mg} \mathrm{CH}_{4} \mathrm{~m}^{-2} \mathrm{~h}^{-1}$, respectively. When compared to each other, there was a large gap in $\mathrm{CH}_{4}$ flux between Chen et al. (2008, 2009a) and the other studies by Ding et al. (2004), Jin et al. (1999), and Hirota et al. (2004). This gap might have been caused by different vegetation types and environmental factors, since mean $\mathrm{CH}_{4}$ fluxes from vulgaris are very close, $11.1 \mathrm{mg} \mathrm{CH}_{4} \mathrm{~m}^{-2} \mathrm{~h}^{-1}$ in Chen et al. (2009b) and $12.1 \mathrm{mg} \mathrm{CH}_{4} \mathrm{~m}^{-2} \mathrm{~h}^{-1}$ in Hirota et al. (2004). Finally, the $\mathrm{CH}_{4}$ flux in Qinghai-Tibet Plateau is $7.38 \mathrm{mg} \mathrm{CH}_{4} \mathrm{~m}^{-2} \mathrm{~h}^{-1}$ by averaging the five $\mathrm{CH}_{4}$ fluxes from the five aforementioned studies, the maximum $\mathrm{CH}_{4}$ release is $15.21 \mathrm{mg} \mathrm{CH}_{4} \mathrm{~m}^{-2} \mathrm{~h}^{-1}$, and the minimum value is $1.69 \mathrm{mg} \mathrm{CH}_{4} \mathrm{~m}^{-2} \mathrm{~h}^{-1}$ (Table 2).

In South China, mangroves are mainly distributed along seaside. The tidal beach marked on the land cover map along seaside is deemed as the mangrove wetland, and the others are considered as herbaceous swamp. Mangrove trees are mainly distributed in Fujian, Guangdong, Guangxi, Taiwan, and Hainan. The measured $\mathrm{CH}_{4}$ release factor of $0.03 \mathrm{mg} \mathrm{CH}_{4} \mathrm{~m}^{-2} \mathrm{~h}^{-1}$ from mangroves in Hainan province by $\mathrm{Lu}$ group $\mathrm{Lu}$ et al. (1999) is used as the $\mathrm{CH}_{4}$ emission rate from mangroves in South China. Tidal beaches in the five provinces are located in South China. The mean $\mathrm{CH}_{4}$ fluxes from herbaceous swamp are obtained by averaging the measured $\mathrm{CH}_{4}$ fluxes in Min River Estuary and in Taiwan, and the averaged value is $2.18 \mathrm{mg} \mathrm{CH}_{4} \mathrm{~m}^{-2} \mathrm{~h}^{-1}$, with maximum of $4.57 \mathrm{mg} \mathrm{CH}$ $\mathrm{m}^{-2} \mathrm{~h}^{-1}$ and the minimum of $0.14 \mathrm{mg} \mathrm{CH}_{4} \mathrm{~m}^{-2} \mathrm{~h}^{-1}$.

In the three geophysical regions of North China, Central China, and Inner Mongolia, mean $\mathrm{CH}_{4}$ flux is calculated by averaging the measured $\mathrm{CH}_{4}$ fluxes from wetlands in their respective regions. Since there is no investigation into $\mathrm{CH}_{4}$ fluxes in Northwest China, the measurements in Wuliangsu Lake are used for the $\mathrm{CH}_{4}$ release from wetlands (Duan et al. 2005), where the environmental conditions are similar 
with that in Northwest China. The detailed information about $\mathrm{CH}_{4}$ release factors in the three geophysical regions is listed in Table 3.

The estimates made in the growing season indicate only a ratio of the measured $\mathrm{CH}_{4}$ flux, as an assumption that is emitted during the unmeasured period (Ding et al. 2004). In Sanjiang Plain, the mean $\mathrm{CH}_{4}$ fluxes (November-April) are 0.5 and $0.18 \mathrm{mg} \mathrm{CH}_{4} \mathrm{~m}^{-2} \mathrm{~h}^{-1}$ for Carex Lasiocarpa and D. angustifolia, respectively (Zhang et al. 2005), which are about 4.35 and $2.88 \%$ of the measured fluxes for the two plants in Song et al. (2008). The averaged contribution of $3.61 \%$ is used to calculate $\mathrm{CH}_{4}$ fluxes during non-growing season in Northeast, North, and Northwest China and Inner Mongolia. In Qinghai-Tibet Plateau, the area-weighted mean $\mathrm{CH}_{4}$ flux is $0.36 \mathrm{mg} \mathrm{CH} \mathrm{Cm}^{-2} \mathrm{~h}^{-1}$, which accounted for $3.00 \%$ of the measured $\mathrm{CH}_{4}$ fluxes by Chen et al. (2008).

The duration of wetland plant growth is a key factor to influence estimation results. It is assumed to be 165 days in plain wetland in Northeast China and 150 days in mountainous area in Northeast China and in Qinghai-Tibet Plateau (Jin et al. 1999). In North, Northwest, South, and Central China, and Inner Mongolia, the measurement period is used as the plant growth duration. In South and Central China, the measurements are conducted around a year; thus, 365 days are used as plant growth period.

Estimate of annual $\mathrm{CH}_{4}$ emission from natural wetland in China

The spatial distribution of annual $\mathrm{CH}_{4}$ emission from natural wetland is described in Fig. 2. The estimated $\mathrm{CH}_{4}$ emissions range from 0 to $5,702.8 \mathrm{~kg}$ per pixel with the area of $1 \mathrm{~km}^{2}$. It is obvious that high $\mathrm{CH}_{4}$ emissions occurred in the North and Northeast area of China, while low values are in the south and east regions. Specifically, the northeast China has the highest contribution to the total $\mathrm{CH}_{4}$ emissions from natural wetland in China (39\%), Inner Mongolia and Qinghai-Tibet highland account for about $25 \%$ and $21 \%$, respectively, and the other $15 \%$ of released $\mathrm{CH}_{4}$ is in northwest, north, central, and south China (Table 4).

The spatial variation in $\mathrm{CH}_{4}$ emissions is strongly correlated with that of the area proportion of wetlands, and their correlation coefficient reaches to 0.90 . This indicates that the spatial variation in $\mathrm{CH}_{4}$ released from natural wetlands is mainly controlled by the area of wetlands. From Tables 2 and 4, the percentages of wetland in Northeast China-plain, Inner Mongolia, Northwest China, and Northeast China-mountain area are lower than their corresponding proportion of $\mathrm{CH}_{4}$ emissions. This might be because of the combined influences of plant types, duration of plant growth, and climatic conditions.

The total $\mathrm{CH}_{4}$ release from Chinese natural wetlands ranges from 3.48 to $7.16 \mathrm{Tg}$ year $^{-1}$, with the mean value of $4.94 \mathrm{Tg} \mathrm{CH}_{4}$ per year. This showed that China had a $4.5 \%$ contribution to global natural wetland $\mathrm{CH}_{4}$ emission levels (110 $\mathrm{Tg} \mathrm{CH}_{4}$ ) (Matthews and Fung 1987). Our estimates are much higher than that by Ding et al. (2004, $1.78 \mathrm{Tg} \mathrm{CH}_{4}$ year $^{-1}$ ), and even the minimum value is about twice by Ding et al. (2004). This was mainly because this study adopted almost twice the wetland area as well as higher $\mathrm{CH}_{4}$ factors. $\mathrm{CH}_{4}$ release factor in Qinghai-Tibet Plateau is $7.38 \mathrm{mg} \mathrm{CH}_{4} \mathrm{~m}^{-2} \mathrm{~h}^{-1}$ used in this study and $2.96 \mathrm{mg} \mathrm{CH}_{4} \mathrm{~m}^{-2} \mathrm{~h}^{-1}$ in Ding et al. (2004). In South China, the $\mathrm{CH}_{4}$ release factor is $0.05 \mathrm{mg} \mathrm{CH}_{4} \mathrm{~m}^{-2} \mathrm{~h}^{-1}$ for mangrove wetland and $2.18 \mathrm{mg} \mathrm{CH} \mathrm{Cm}_{4} \mathrm{~m}^{-1}$ for herbaceous swamp in this study, while 0.05 for all of the wetland in Ding et al. (2004). There are also some studies on estimating $\mathrm{CH}_{4}$ emissions in local areas. In Qinghai-Tibet

Table $3 \mathrm{CH}_{4}$ fluxes from natural wetlands and duration of plant growth in China

\begin{tabular}{|c|c|c|c|c|}
\hline Geophysical region & $\begin{array}{l}\text { Mean/maximum/minimum } \mathrm{CH}_{4} \\
\text { fluxes during growth period } \\
\left(\mathrm{mg} \mathrm{CH}_{4} \mathrm{~m}^{-2} \mathrm{~h}^{-1}\right)\end{array}$ & $\begin{array}{l}\text { Duration of measurement } \\
\text { period (days)/begin-end } \\
\text { (months) }\end{array}$ & $\begin{array}{l}\text { Mean/maximum/minimum } \\
\mathrm{CH}_{4} \text { fluxes during non-growth } \\
\text { period }\left(\mathrm{mg} \mathrm{CH} \mathrm{CH}_{4}^{-2} \mathrm{~h}^{-1}\right)\end{array}$ & $\begin{array}{l}\text { Duration of non- } \\
\text { measured period } \\
\text { (days) }\end{array}$ \\
\hline $\begin{array}{l}\text { Northeast China-Mountain } \\
\text { area }\end{array}$ & $11.60 / 11.60 / 11.60$ & $150 / 5-10$ & $0.42 / 0.42 / 0.42$ & 215 \\
\hline Northeast China-Plain & $12.03 / 17.59 / 9.55$ & $165 / 5-10$ & $0.43 / 0.64 / 0.34$ & 200 \\
\hline North China & $0.52 / 0.52 / 0.52$ & $240 / 4-11$ & $0.02 / 0.02 / 0.02$ & 125 \\
\hline Qinghai-Tibet Plateau & $7.38 / 15.21 / 1.69$ & $150 / 5-9$ & $0.22 / 0.46 / 0.05$ & 215 \\
\hline Northwest China & $8.75 / 8.75 / 8.75$ & $210 / 4-10$ & $0.32 / 0.32 / 0.32$ & 154 \\
\hline Inner Mongolia & $10.97 / 13.18 / 8.75$ & $210 / 4-10$ & $0.40 / 0.48 / 0.32$ & 154 \\
\hline Central China & $2.2 / 3.35 / 1.05$ & $365 / 1-12$ & & 0 \\
\hline South China-mangroves & $0.03 / 0.03 / 0.03$ & $365 / 1-12$ & & 0 \\
\hline $\begin{array}{l}\text { South China-herbaceous } \\
\text { swamp }\end{array}$ & $2.18 / 4.57 / 0.14$ & $365 / 1-12$ & & 0 \\
\hline
\end{tabular}




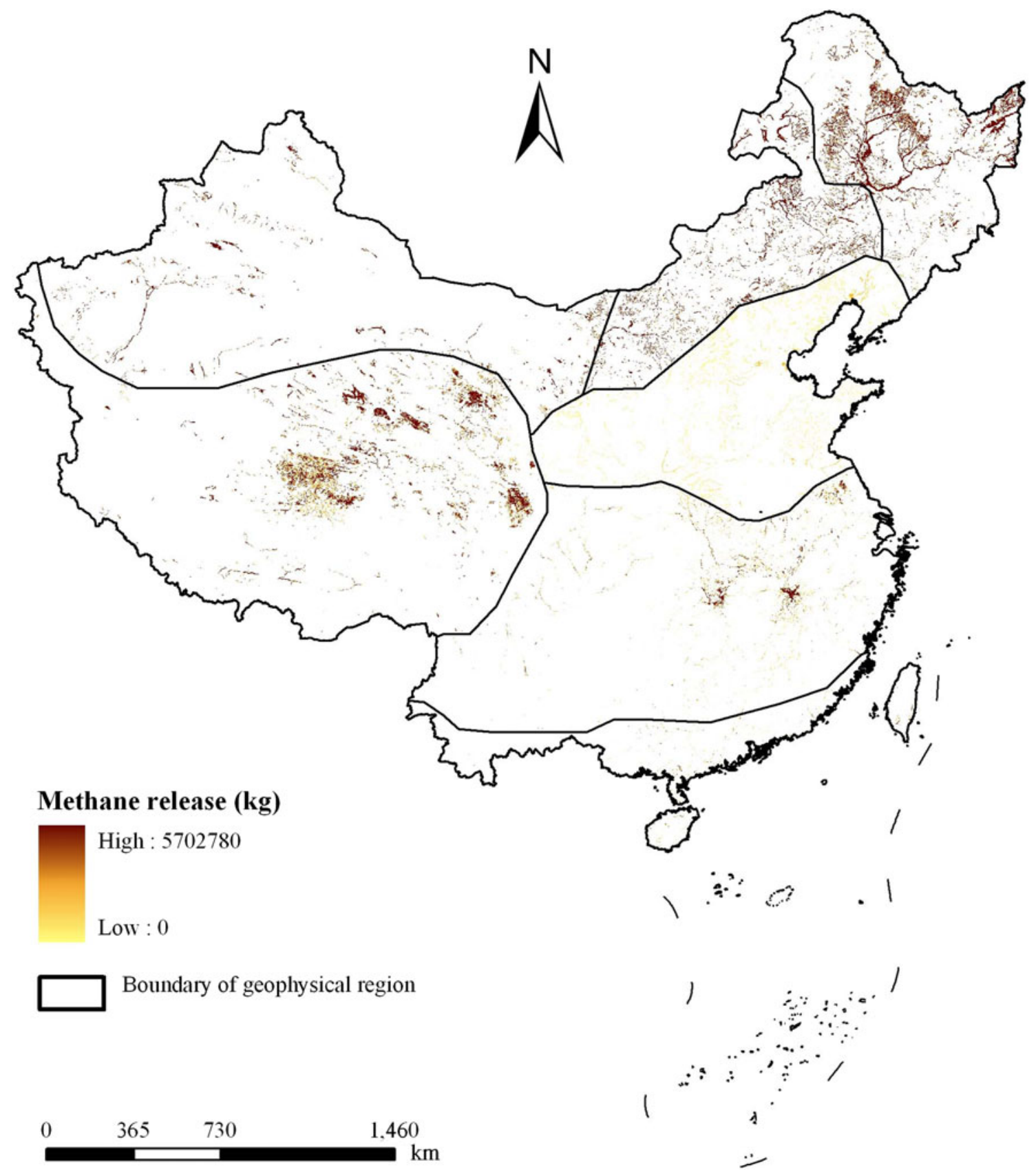

Fig. 2 Spatial distribution of estimated $\mathrm{CH}_{4}$ emissions

Plateau, the annual $\mathrm{CH}_{4}$ release is $0.90 \mathrm{Tg}$ from $133,000 \mathrm{~km}^{2}$ wetlands by Jin et al. (1999), $0.56 \mathrm{Tg}$ from 48, $073 \mathrm{~km}^{2}$ wetlands by Ding et al. (2004), and $1.04 \mathrm{Tg}$ from $37,577 \mathrm{~km}^{2}$ wetlands in this study. The two latter estimates are conducted only based on their measurements, while our estimate involves these two measurements and other investigations in recent results. Wang et al. (2005) also reported that the averaged $\mathrm{CH}_{4}$ emission rate for riparian mires in semiarid area was at the upper end of the range reported previous studies of natural wetlands in China, and if their result is considered in the calculation of $\mathrm{CH}_{4}$ emission from natural wetlands of China, total flux is probably larger than the latest estimate of $1.76 \mathrm{Tg} \mathrm{CH}_{4}$ year $^{-1}$.

Compared with the earlier estimation, this study contains several improvements. First, the natural wetland map is used to estimate $\mathrm{CH}_{4}$ releases at per $\mathrm{km}^{2}$, and the spatial distribution of $\mathrm{CH}_{4}$ emissions is firstly obtained in China. Second, the simplified differentiation of wetland types by Ding et al. (2004) does not fit to estimate $\mathrm{CH}_{4}$ efflux, since $\mathrm{CH}_{4}$ emissions is also greatly influenced by plant, climate, and other environmental factors. In the current approach, 
Table 4 Statistics of $\mathrm{CH}_{4}$ release from natural wetland (excluding water surface) area by geographical regions in China

\begin{tabular}{lcc}
\hline $\begin{array}{l}\text { Physico-geographical } \\
\text { regions }\end{array}$ & $\begin{array}{l}\mathrm{CH}_{4} \text { emissions } \\
\left(\mathrm{Gg} \mathrm{year}^{-1}\right)\end{array}$ & \multicolumn{1}{c}{$\begin{array}{l}\text { Proportion } \\
(\%)\end{array}$} \\
\hline South China & 17.08 & 0.35 \\
South China-Mangrove & 0.27 & 0.01 \\
Central China & 191.66 & 3.88 \\
Qinghai-Tibet Plateau & $1,040.86$ & 21.09 \\
Northwest China & 468.90 & 9.50 \\
Inner Mongolia & $1,237.06$ & 25.06 \\
North China & 31.90 & 0.65 \\
Northeast China-mountain area & 440.09 & 8.92 \\
Northeast China-plain & $1,507.79$ & 30.55 \\
Total & $4,935.61$ & 100.00 \\
\hline
\end{tabular}

geophysical regions and vegetation portion are considered to take into account the effects of climate and plant on $\mathrm{CH}_{4}$ efflux. Finally, $\mathrm{CH}_{4}$ release factor is updated with the recent scientific literature. In Ding et al. (2004), only four measurements were used to estimate $\mathrm{CH}_{4}$ emission levels in China, while in this study, more than 25 investigations are used to calculate the total emissions. These 25 investigations are distributed around China, not only located in Qinghai-Tibet and Northeast China. These new measurements are not supplementary to the existed measurements on $\mathrm{CH}_{4}$ emission in Northeast China and Qinghai-Tibet Plateau, but also provide new information in the unmeasured areas. For example, in Ding et al. (2004), $\mathrm{CH}_{4}$ emission from salt marsh was not included since there were no measured $\mathrm{CH}_{4}$ fluxes. However, $\mathrm{CH}_{4}$ emission from salt marsh is not insignificant and so should not be negligible (Magenheimer et al. 1996; Tong et al. 2010).

Uncertainty analysis and future research needs

Due to the simplified nature of $\mathrm{CH}_{4}$ release calculations, the uncertainty of the final efflux estimation could be evaluated only qualitatively. This evaluation is performed using the scale created for atmospheric emissions. The uncertainty scale $\mathrm{C}$ is defined as that an estimate based on a number of measurements made at a small number of representative facilities, and the typical error rate is $50-150 \%$; scale D is defined as that an estimate based on single measurements, and typical error rate is $100-300 \%$ (UNECE 2004). According to the definitions on uncertainty scale, the estimates on $\mathrm{CH}_{4}$ emissions in North, Northwest, mountain areas in Northeast China belong to uncertainty scale $\mathrm{D}$, and the others are scale $\mathrm{C}$. Although the Chinese territory is divided into 7 geophysical regions to represent the regional difference between climate and soil condition, strong variations are also found in measured
$\mathrm{CH}_{4}$ effluxes in each region. Therefore, with additional field measurements of $\mathrm{CH}_{4}$ flux, an improved assessment of $\mathrm{CH}_{4}$ emission from natural wetlands of China may be possible.

The uncertainties of $\mathrm{CH}_{4}$ release estimates arise from uncertainties in the prediction of the area of natural wetland. The areas of natural wetland (including water surface) in China show large gaps from different sources and by different studies, $152,000 \mathrm{~km}^{2}$ determined by Changchun Institute of Geography, Chinese Academy of Sciences, $256,878 \mathrm{~km}^{2}$ extracted from 2000 National Land Survey Data, 224,568 $\mathrm{km}^{2}$ by East China Normal University, and $359,478 \mathrm{~km}^{2}$ identified from remote sensing data (Niu et al. 2009). The strong variations in natural wetland areas are directly important causes of the gaps, which estimated $\mathrm{CH}_{4}$ emissions in China between different studies. Moreover, China's natural wetlands are disappearing even faster than feared, $33 \%$ of which were lost between 1978 and 2008 (Gong et al. 2010). In this study, the 2000 National Land Survey Data is used, and by now the wetland might have decreased further, and the annual $\mathrm{CH}_{4}$ release might be higher estimated in this study.

In this study, the influence of soil conditions on $\mathrm{CH}_{4}$ release is not considered. Methane emission from wetlands results from the interaction between several biological and physical processes in the soil, which is strongly regulated by the amount and quality of available substrate, $\mathrm{pH}$, and temperature (Yavitt and Lang 1990; Westermann 1996). Moreover, the amount of total $\mathrm{N}$ and organic $\mathrm{C}$ in the soils corresponded roughly with the mean rates of $\mathrm{CH}_{4}$ emission from mire hollows in different riparian sites (Wang et al. 2005). In further study in estimating $\mathrm{CH}_{4}$ emissions from natural wetland, a detailed soil map on physical characteristics should be provided.

\section{Conclusion}

As mentioned in Introduction section, numerous studies are conducted to measure the rate of $\mathrm{CH}_{4}$ fluxes in different regions, but just few estimates about overall geographical $\mathrm{CH}_{4}$ emissions in China. Based on the spatial distribution of wetland, plant types, duration of plant growth, and geophysical divisions, this study firstly estimates the spatial variations in annual $\mathrm{CH}_{4}$ emissions from natural wetlands excluding water surface in China, with the pixel size of $1 \mathrm{~km} \times 1 \mathrm{~km}$. The estimated annual $\mathrm{CH}_{4}$ emissions range from 0 to $5702.8 \mathrm{~kg}$ per pixel with the area of $1 \mathrm{~km}^{2}$, and the spatial variation in $\mathrm{CH}_{4}$ emissions is strong correlated with that of wetlands. The total $\mathrm{CH}_{4}$ emission from natural wetland in China was $4.94 \mathrm{Tg}$ year $^{-1}$, higher than that by Ding et al. (2004) since the larger areas of natural wetland and higher $\mathrm{CH}_{4}$ release factor are used. The wetland in 
northeast China had the highest contribution to the total $\mathrm{CH}_{4}$ emissions in China, Inner Mongolia and QinghaiTibet highlands had the second highest contribution, and northwest, north, central, and south China had the least.

Acknowledgments Funding support was from the Specialized Research Fund for the Doctoral Program of Higher Education of China (20100091120017), National Natural Science Foundation of China (41101315 and 41171324), funding of visiting scholar project by CSC(201208320130), Fundamental Research Funds for the Central Universities, and the Priority Academic Program Development of Jiangsu Higher Education Institutions.

\section{References}

Bachelet D, Neue HU (1993) Sources and sinks of methane. NATO ASI Series 13:457-465

Bicheldey TK, Latushkina EN (2010) Biogass emission prognosis at the landfills. Int J Environ Sci Technol 7(4):623-628

Chang T, Yang S (2003) Methane emission from wetlands in Taiwan. Atmos Environ 37:4551-4558

Chen H, Yao S, Wu N, Wang Y, Luo P, Tian J, Gao Y, Sun G (2008) Determinants influencing seasonal variations of methane emissions from alpine wetlands in Zoige Plateau and their implication. J Geophys Res 113:D12303. doi:1029/2006JD008072

Chen H, Wu N, Gao Y, Wang Y, Luo P, Tian J (2009a) Spatial variations on methane emissions from Zoige alpine wetlands of Southwest China. Sci Total Environ 407:1097-1104

Chen H, Wu N, Yao S, Gao Y, Zhu D, Wang Y, Xiong W, Yuan X (2009b) High methane emissions from a littoral zone on the Qinghai-Tibetan Plateau. Atmos Environ 43:4995-5000

Ding W, Cai Z (2007) Methane emission from natural wetlands in China: summary of years 1995-2004 studies. Pedosphere 17:475-486

Ding W, Cai Z, Wang D (2004) Preliminary budget of methane emissions from natural wetlands in China. Atmos Environ 38:751-759

Ding W, Cai Z, Tsuruta H (2005) Plant species effects on methane emissions from freshwater marshes. Atmos Environ 39:3199-3207

Duan X, Wang X, Mu Y, Ouyang Z (2005) Seasonal and diurnal variations in methane emissions from Wuliangsu Lake in arid regions of China. Atmos Environ 39:4479-4487

Gong P, Niu ZG, Cheng XA, Zhao KY, Zhou DM, Guo JH, Liang L, Wang XF, Li DD, Huang HB, Wang Y, Wang K, Li WN, Wang XW, Ying Q, Yang ZZ, Ye YF, Li Z, Zhuang DF, Chi YB, Zhou HZ, Yan J (2010) China's wetland change (1990-2000) determined by remote sensing. Sci China Earth Sci 53(7):1036-1042

Hirota M, Tang Y, Hu Q, Hirata S, Kato T, Mo W, Cao G, Mariko S (2004) Methane emissions from different vegetation zones in a Qinghai-Tibetan Plateau wetland. Soil Biol Biochem 36:737-748

Huang G, Li X, Hu Y, Shi Y, Xiao D (2011) Methane $\left(\mathrm{CH}_{4}\right)$ emission from a natural wetland of Northern China. J Environ Sci Heal A 40:1227-1238

Jin H, Wu J, Cheng G, Tomoko N, Sun G (1999) Methane emissions from wetlands on the Qinghai-Tibet Plateau. Chin Sci Bull 44:2282-2286

Lu C, Wong Y, Tam NFY, Ye Y, Lin P (1999) Methane fluxes and production from sediments of a mangrove wetland on Hainan Island, China. Mangroves Salt Marshes 3(1):41-49
Magenheimer JF, Moore TR, Chmura GL, Daoust RJ (1996) Methane and carbon dioxide flux from a macrotidal salt marsh, Bay of Fundy, New Brunswick. Estuaries 19:139-145

Matthews E, Fung I (1987) Methane emission from natural wetlands: global distribution, area, and environmental characteristics of sources. Glob Biogeochem Cy 1:61-86

Niu Z, Gong P, Cheng X, Guo J, Wang L, Huang H, Shen S, Wu Y, Wang X, Wang X, Ying Q, Liang L, Zhang L, Wang L, Yao Q, Yang Z, Guo Z, Dai Y (2009) Geographical characteristics of China's wetlands derived from remotely sensed data. Sci China Ser D 52:723-738

Song C, Wang Y, Wang Y, Zhao Z (2006) Emission of $\mathrm{CO}_{2}, \mathrm{CH}_{4}$, and $\mathrm{N}_{2} \mathrm{O}$ from freshwater marsh during freeze-thaw period in Northeast of China. Atmos Environ 40:6879-6885

Song C, Zhang J, Wang Y, Wang Y, Zhao Z (2008) Emission of $\mathrm{CO}_{2}$, $\mathrm{CH}_{4}$, and $\mathrm{N}_{2} \mathrm{O}$ from freshwater marsh in northeast of China. J Environ Manage 88:428-436

Sun X, Mu C, Song C (2011) Seasonal and spatial variations of methane emissions from montane wetlands in Northeast China. Atmos Environ 45:1809-1816

Tong C, Wang WQ, Zeng CS, Marrs R (2010) Methane $\left(\mathrm{CH}_{4}\right)$ emission from a tidal marsh in the Min River estuary, southeast China. J Environ Sci Heal A 45:506-516

UNECE (2004) EMEP/CORINAIR Atmospheric emission inventory guidebook, 4th edn. European Environment Agency, Copenhagen. (http://reports.eea.eu.int/EMEPCORINAIR4/enS)

Wang Z, Han XG, Li LH, Chen QS (2005) Methane emission from small wetlands and implications for semiarid region budgets. J Geophys Res 110:D13304

Wang H, Lu J, Wang W, Yang L, Yin C (2006) Methane fluxes from the littoral zone of hypereutrophic Taihu Lake, China. J Geophys Res 111:D17109. doi:10.1029/2005JD006864

Wang QD, Chen ZL, Xu SY (2009a) Methane emission from Yangtze estuarine wetland, China. J Geophys Res 114:G02011. doi:10. 1029/2008JG000857

Wang Z, Song Y, Gulledge J, Yu Q, Liu H, Han X (2009b) China's grazed temperate grasslands are a net source of atmospheric methane. Atmos Environ 43:2148-2153

Westermann P (1996) Temperature regulation of anaerobic degradation of organic matter. World $\mathrm{J}$ Microbiol Biotechnol 12:497-503

Yavitt JB, Lang GR (1990) Methane production in contrasting wetland sites: response to organic-chemical components of peat and to sulfate reduction. Geomicrobiol J 8:27-46

Yavitt JB, Lang GE, Downey DM (1988) Potential methane production and methane oxidation rates in peatland ecosystems of the Appalachian Mountain United States. Glob Biogeochem Cy 2:253-268

Zhang JB, Song CC, Yang WY (2005) Cold season $\mathrm{CH}_{4}, \mathrm{CO}_{2}$ and $\mathrm{N}_{2} \mathrm{O}$ fluxes from freshwater marshes in northeast China. Chemosphere 59:1703-1705

Zhang XY, Jiang H, Wang YQ, Hand Y, Buchwitz M, Schneising O, Burrows JP (2011) Spatial variations of atmospheric methane concentrations in China. Int J Remote Sens 32:833-847

Zhang XY, Jiang H, Zhou GM, Xiao ZY, Zhang Z (2012) Geostatistical interpolation of missing data and downscalling of spatial resolution for remotely sensed atmospheric methane column concentrations. Int J Remote Sens 33:1-15

Zhu D, Chen H, Wu N, Wang Y, Luo P (2011) Winter methane emission from an alpine open fen on Tibetan Plateau. Pol J Ecol 59:87-94 